\title{
3. Clerical and Ecclesiastical Ideas of Territory in the Late Medieval Low Countries
}

\author{
Bram van den Hoven van Genderen*
}

\begin{abstract}
Stuart Elden's The Birth of Territory relies heavily on political theorists and lexical analysis; this chapter argues that the Church and clerics had an important impact Elden overlooked. Late medieval parishes and bishoprics had contiguous borders, fiscal and administrative procedures and powers, their own jurisdiction, and their own hierarchy. A bishop had, in a sense, his own territory. The chapter first discusses general ideas of geography and the specific Christian geography of two important mid-fifteenth-century clerics: (the later) Pope Pius II and Cardinal Nicholas of Cusa. It then highlights the importance of parishes and bishoprics as typical structural elements of ecclesiastical 'territories'. Finally, it provides detailed analysis of the territorial features of the creation of new bishoprics in the Low Countries in 1559.
\end{abstract}

Keywords: ecclesiastical territory; parish; bishopric; christianitas; new bishoprics of 1559

Susan Reynolds has warned scholars about the danger of attributing too easily the same meaning and interpretation to similar words in different periods - words such as 'community', 'college', or 'university'. Her most famous

* In this article I do not pretend to present an exhaustive or systematic overview of the literature. Thanks again to my friend Martin Yates for the correcting of the text. Only after finishing this article I got hold of a copy of Florian Mazel's excellent 2016 book L'évêque et le territoire, otherwise unavailable in libraries of the Low Countries. He addresses some of the topics of my article, stressing the importance of visitations, fiscal registers, inventories, and other administrative tools, resulting in an ecclesiastical idea and use of territory. I was able to refer to this book in some of the footnotes, but due to a lack of space could not discuss his ideas extensively in the corpus of the text.

Damen, M. and K. Overlaet (eds.), Constructing and Representing Territory in Late Medieval and Early Modern Europe. Amsterdam: Amsterdam University Press, 2022 DOI 10.5117/9789463726139_CHO3 
example was, of course, the history of the vague construct 'feudalism.' ${ }^{1}$ The use of concepts, keywords, or Grundbegriffe is always tricky, especially when they seem to suggest a solid basis for research or provide a clear notion of the temporal and spatial development of a certain phenomenon or idea. In a way, the political geographer Stuart Elden, in his search for the idea of 'territory', shows the perils of such a narrow approach. In the clear overview he presents in his book The Birth of Territory (2013) and even more so in his article 'How Should We Do the History of Territory?' (2013), he ends up concluding that important concepts such as 'space, the territory, and the population', as used by Foucault, 'emerged, at least in a recognisably modern sense, at a similar historical juncture'. ${ }^{2}$ Although he clearly states that he did not write a history of territory 'in the sense that territory is an ahistorical category which has been understood and practiced in different ways at different times', he nevertheless uses a historical order and chronology, divided into time periods, to suggest development, maybe even progress, especially in his use of physical denominators such as 'The Birth'. ${ }^{3}$ By concentrating on the ideas of 'the secular political theorists of temporal power' and 'the lack of conceptual tools' in the pre-modern period, he employs a teleological method that brings with it the imminent danger of constructing a circular argument. ${ }^{4}$ First, define your ideas, your concept of territory, in a modern sense, or at least in the way Foucault saw them from the seventeenth century onwards, and then search for them in the course of history, finding them, of course, for the first time in a full-blown sense in the seventeenth century. 5 An example can show the dangers of such an approach, based only on the writings of 'grand theorists'. One of

\footnotetext{
1 Reynolds, Fiefs and Vassals; Reynolds, Kingdoms and Communities, p. xliv: 'When words such as universitas, collegium, communia, or communitas occur in medieval sources in contexts that seem to suggest something like what a modern lawyer means by a corporate group (though legal definitions are less simple than historians of medieval political thought sometimes imply), that does not mean that anyone in the Middle Ages, even academic lawyers, had anything like the modern legal concept in their minds.'

2 Elden, The Birth; Elden, 'How Should We Do the History of Territory?', pp. 11-12. See also the inspiration he derived from the German tradition of Begriffsgeschichte, as mentioned on p. 15 . For a short overview of Elden's ideas see the introduction of Damen and Overlaet in this volume. For an earlier concept of population and its uses, at least to me quite recognisable: Biller, The Measure of Multitude, e.g. pp. $385-419$, admitting some doubts in comparison to the modern concept of demography.

3 Elden, 'How Should We Do the History of Territory?', p. 15.

4 Ibid., p. 16.

5 See ibid., p. 17: 'To control territory requires the subjugation of the people; to govern the population requires command of the land.'
} 
the most crucial concepts of the Later Middle Ages is the commune bonum, the 'common good' or the 'commonwealth'. Looking at philosophical or theological works one usually comes to the conclusion that this original Aristotelian concept was first reintroduced by John of Salisbury in the 1150s, but really became important through its systematic implementation by Thomas Aquinas a century later. However, in a charter for the Flemish town of Aire-sur-la-Lys, from 1093-1111, such a principle is already given pride of place. ${ }^{6}$ The history of this political and social concept is older by a century and a half than otherwise assumed, by looking at documents and historical practice instead of merely consulting philosophical works. Another warning is Seb Falk's recent statement in his book on medieval science:

The measure of medieval ideas should never be how closely do they match our superior modern ways?', but rather 'how important were they in their time?', and 'what impact did they have?' [...] Progress there undoubtedly has been, but it has not been a series of 'Eureka' moments by great men. ${ }^{7}$

Of course, we ought to take the latter's theories into consideration, but we should not stop there.

\section{Clerical ideas}

From all this it becomes clear that Elden gives pride of place and primacy to political theory. ${ }^{8}$ The way in which he utilises the ideas of Foucault is of interest. The latter, in Elden's words, notifies 'four registers - economic, strategic, legal and technical - [which] taken together, are crucial in addressing the political and historical specificities of territory.' ${ }^{9}$ In his reading of Foucault, he does not use or comment on the role of religion, however

6 Stein, Boele and Blockmans, 'Whose Community?', pp. 149-151: 'ad honorem et utilitatem totius ville', with more examples in the following pages. For many of its practical implications: Rawcliffe, Urban Bodies. For much of the scholastic theory: Kempshall, Common Good.

$7 \quad$ Falk, The Light Ages, p. 9.

8 He himself notes that another tradition existed: Roman law, not based on Greek political thought. He mentions writers like Bartolus, who are clear on the relation between territorium and jurisdiction. 'But, surprisingly, their work seems to have no discernible impact in political theory for some time.' Quote from Elden, 'How Should We Do the History of Territory?', p. 16. For more detail, see Elden, The Birth, pp. 218-228.

9 Elden, 'How Should We Do the History of Territory?', p. 7. 
(as Foucault did). ${ }^{10}$ In this volume, which concentrates on the fluidity and multiplicity of the concept of territory before the modern period and likewise on the political practices of lay rulers, an attempt to investigate (possibly converging) clerical ideas and practices could have added value. ${ }^{11}$ I will show how the Church and its institutions employed all kinds of territorial concepts and practices usually associated with lay rulers and their emerging states, often before the latter. Contiguous borders as well as fiscal, administrative, and legal theories and practices can all be found in the ecclesiastical sources, along with hierarchical ordering, abstract concepts, and the application of population numbers. All of these clerical contributions to the evolution of the idea of what a territory might be are just as much stepping stones in the development of 'the birth of territories' as those Elden describes, but are left out by him altogether, however undeservedly. ${ }^{12}$

This task is highly complex. Due to a lack of research on the subject, it is not possible to provide more than an initial and limited introduction. ${ }^{13}$ I will mainly concentrate on an area with which I am familiar: the Low Countries in the Later Middle Ages and the beginnings of the early modern period. ${ }^{14}$ I will start, however, with a discussion of some of the general ideas

10 Religion plays, however, a not unimportant role in Foucault's work. Among studies concentrating on power and religion in the work of Foucault: Strenski, 'Religion, Power, and Final Foucault'; Carette, Foucault and Religion, esp. pp. 129-141, with this on p. 136: '[...] Christianity in particular creates "forms of subjection" by developing "new power relations"'; and especially Holland, “'Truth as Force"'. Characteristically, religion does not feature much in Elden's Foucault: The Birth of Power, see, however, pp. 25-27 and 96-97.

11 See also the general remarks on the approaches to 'territory' of Damen and Overlaet in the introduction to this volume.

12 See, for instance, the lucid remarks of Schmidt, 'Neugliederung', pp. 107-111: 'Die hierarische Struktur der Kirche verteilte Kompetenzen, legte Befehlsgewalten und Partizipationen fest. Zuständigkeiten waren auf Räume bezogen. Ihre Gliederung musste stabil sein, weil nur so das Ideal eines brüderlichen Einvernehmen zwischen den Leitern der Raumeinheiten gewährleistet sein könnte. [...] Das vierte Laterankonzil von 1215 verfügte daher folgerichtig die Bindung jedes Gläubigen an eine Pfarrei, schützte den Bestand der Bistümer und Kirchenprovinzen vor Veränderungen, selbst wenn damit Anachronismen im Kauf genommen werden mussten, legte einen Instanzweg von den kleinen zu den grösseren Raumeinheiten fest und stabilisierte damit eine räumlichen Gefüge, das Papst Innozenz III. und die Konzilsvater als Voraussetzung für die gute Ordnung der res publica ansahen, als die Kirche neben anderen Termini bezeichnet wurde' (p. 107).

13 See, however, the articles of Schmidt and the concluding quote of Mazel at the end of this chapter, and more generally his book L'évêque et le territoire.

14 Following here Goetz, 'Discourses on Purity', p. 116: 'As far as I see, research on the Christian Middle Ages has not yet reached the stage that would allow me to simply provide a summarising survey. Consequently, my analysis had to draw more or less directly on the sources, which, in a brief paper, can only be done on the basis of some examples. I shall restrict my remarks to the 
of geography, and the more specific Christian geography, of two important mid-fifteenth-century clerics: (the later) Pope Pius II and Cardinal Nicholas of Cusa. After presenting a sketch of the broad idea of 'Christian territory', I will highlight the importance of two concrete entities - parishes and bishoprics - which are two of the typical structural elements of ecclesiastical 'territories'. Finally, a more detailed analysis will be given of 'practices', namely of the territorial features of the creation of new bishoprics in the Low Countries in 1559.

Structural elements and general ideas will concern us mostly, hereafter. Instead of merely focusing on structures and on jurisdictions, we can, however, also look at the way clerics identified themselves or were identified by others. In the papal administration, the largest bureaucracy at the time, and also in the ordinances of universities, students or clerics were often denominated by their diocese, as was, of course, the general rule for a cleric: they were first and foremost clericus Traiectensis or clericus $N$. for another diocese. Sometimes a region, the town, or a denomination like presbyter or notary was added. The system was simple to use, fairly trustworthy, and easy recognisable across all of Christendom, although silly mistakes and misunderstandings were certainly possible, such as curial clerks in Rome labelling Denmark "in Africa" or placing the (Lower Saxony) bishopric of Hildesheim in Bavaria in an overview of Christian bishoprics. ${ }^{15} \mathrm{~A}$ very elaborate example of such an identification is the following, taken from the diary of an early-sixteenth-century cleric, who lived for decades in Rome and who presented himself as 'Cornelius de Fine filius quondam Joannis de Fine natione Alemannus inferius ducatus Brabantiae et patria Bergensis supra Somam non procul ab Antverpia emporio famoso. ${ }^{16}$ A description containing an impressive amount of detail! He mentions his father, his nation, the Duchy of Brabant, his hometown, Bergen op Zoom, and by way of further explanation its situation not far from the famous market of Antwerp. Usually the diocese is, however, the foremost denominator, although here it is superseded by a reference to a nation, a duchy, and a

earlier Middle Ages with which I am more familiar. The second problem, however, is of really existential significance and refers to the state of sources: Christianity does not know specific commandments on ritual purity and, consequently, it hardly knows any coherent discourses on purity.'

15 Tewes, 'Das Spätmittelalterliche Papsttum', p. 6o8. The register was a new, up-to-date copy of the Provinciale Romanum.

16 Quoted in Schuchard and Schulz, Thomas Giese, p. 88, with many other examples of clerics denominated by their diocese or their town of origin. 
hometown, maybe under the influence of a decades-long stay in the Rome of the High Renaissance.

It goes without saying that many medieval political thinkers were clerics, too. Apart from that, we can distinguish two strands of clerical thinking about territory, and territorial ideas and practices: on the one hand, there is a shared idea of Christian space, and on the other hand, the particular construction and formation of ecclesiastical territory. In its widest sense, clerical ideas knew no limits. For Augustine, the true Church could be identified with the trans-spatial and trans-temporal City of God. ${ }^{17}$ This unworldly concept is neatly epitomised by Cardinal Nicholas of Cusa in his reform proposal for the Church (1459):

Since, however, the church of God is the mystical body of Christ, rightly likened by the apostle to the human body, in which, in the life-giving Spirit, all members are united, so that they might live, just as all members of Christ are given life in the whole body of the church by the Spirit of Christ, to whom all the faithful in this world adhere though faith. ${ }^{18}$

Cusa himself hardly uses the term 'Europe' in his work. According to Tilman Borsche, in Cusa's mind Europe was not so much a geographical entity 'as a spiritual community'. ${ }^{19}$ Christians lived under all kinds of different, sometimes overlapping, jurisdictions. 'The bonding element in this multiplicity and diversity, creating unity, is the verdict, the law, and the power of the general (catholic) Church.' In Cusa's words, it was 'the unity of the faithful which we call the Church'. ${ }^{20}$

Cusa, however, presents an open view of the world and its history here. Although he contrasts Christian truth with non-Christian errors, he nevertheless claims that all religions basically venerate one God, the Christian God, the famous una religio in rituum varietate. ${ }^{21}$ It was not the differences,

17 Oakley, Mortgage of the Past, p. 202.

18 Quoted from the translation by Watanabe and Izbicki, 'A General Reform', p. 191. For Cusa and his work, see the latest sketch by Schwaetzer, 'Nikolaus von Kues', with references to authors such as Erich Meuthen, the Acta Cusana, and the Opera omnia.

19 Borsche, 'Die verborgene Kirche', p. 51: 'als vielmehr eine geistige Gemeinschaft'.

20 Ibid., p. 52: 'Das verbindende, einheitsstiftende Band dieser Vielfalt ist das Wort, das Gesetz und die Macht der allgemeinen (katholischen) Kirche'; in Cusa's words: 'unitas fidelium, quam nos ecclesiam dicimus'.

21 Gebel, Nikolaus von Kues, pp. 134-135. Prophets were sent to all nations, which venerate the same God under different names. For the continuity of the idea, that all other religions were, as sects, derivative of the Christian religion: Akbari, Idols in the East, especially chap. 5; Tolan, 'Conquest and Its Justifications', pp. 32-40; Tolan, Saracens, pp. 40-57 and 69-134. 
but the connections and the similarities that mattered. Christ was the King of Kings, standing at the apex of a hierarchy. After Him came the Christian king, who 'ruled according to natural law, the laws of both testaments, and the true faith'. ${ }^{22}$ He was followed by the sultan, the king of the Mohammedan sect, and the king of the Tatars. In Gebel's words:

This 'graduatio' idea is also the cornerstone of Nicholas' idea of the Church. In its widest sense the Church is formed by all creatures of sense, by people and rational minds, all connected to Christ, their head, albeit in different steps. All people have, however, a share in this 'ratio', although in different degrees. ${ }^{23}$

Ratio, the acknowledgement of the Christian truth, and through it the law and the power of the Church, delineate the world and its territories in this broad view.

Aeneas Silvius Piccolomini (1405-1464) is less open-minded but just as interesting. One of the most intriguing characters of the fifteenth century, he was born into a noble family, received an excellent university education, and was prolific as a humanist writer of letters, treatises, poems, histories, commentaries-cum-memoirs, and a mix of historical-geographical narratives. He became a secretary and diplomat, and was active at the Council of Basel (1432-1449) and at the court of Emperor Frederick III (r. 1440-1493), before pursuing a real clerical career, becoming a bishop first, a cardinal later, and finally Pope Pius II (1458-1464). ${ }^{24}$

The life of Pius (like that of Cusa) revolved around the struggle between the conciliar movement and the pope, and around the imminent danger posed by the Turks, especially after the fall of Constantinople in 1453. This last threat was one of the defining elements of Pius's 'cosmographical' work. In 1461 he composed his work $A$ sia. ${ }^{25}$ In it he claims to give an up-to-date

22 Gebel, Nikolaus von Kues, p. 160.

23 Ibid., p. 180: 'Grundlegend ist der "graduatio"-Gedanke auch für Nikolaus' Kirchenbegriff. Die Kirche im weitesten Sinne besteht für ihn aus allen vernüftigen Kreaturen, aus Menschen und rationalen Geistern, die mit Christus, ihrem Haupt, auf verschiedenen Stufen verbunden sind. Alle Menschen haben aber, wenn auch in verschiedenem Grade, Anteil an der "ratio".' 24 The latest biography I am aware of is Reinhardt, Pius II. On the political problems of the curia and the conciliar movement, see O'Brien, Commentaries. See also the introduction to Reject Aeneas, pp. 1-57, and the introduction by Von Martels in Enea Silvio, pp. 25-102; furthermore, the introduction of Nancy Bisaha in Piccolomini, Europe, with all the literature mentioned in these works.

25 I will refrain from a more general overview of the cosmographical and cartographic ideas. See, for instance, in general, Cosgrove, Apollo's Eye. Central here is Oschema, Bildervon Europa, 
history of a part of Asia, however he pays no attention to the role of the Mongols. It is more of a summary, a humanist recapitulation of ancient geographical knowledge, although Pius is certainly not a simple copyist of antique sources. His main targets were the Turks, cast as the barbarous Scythians of old, without 'any redeeming virtues'. His purpose was to launch a new crusade against the Turks. ${ }^{26}$ Pius saw the non-European world from the perspective of the different, consecutive world empires. Once there had been a universal Church, but now it had shrunk due to the expansion of 'sects' like Islam into Europe. The result was a Europe which had at its core the values of Christian unity and the culture of the liberal arts and classical rhetoric. His ultimate goal was Christian unity and unification, to be brought about by the reintegration of the orthodox churches and the conversion of Muslims, resulting in a general peace. ${ }^{27}$

Three years earlier, while still a cardinal, he had written De Europa (1458). Although this book was meant to record 'the most memorable deeds accomplished among the Europeans and the islanders who are counted as Christian during the reign of Emperor Frederick III', it also contains geographical descriptions. It gives a unique view of Europe's topography by a cleric. His impressive tour starts in Hungary, Valachia (Wallachia), and Greece, and continues through Austria, Poland, Saxony, Scandinavia, Frisia, Holland, Utrecht, Ghent, France, and England, ending up with a lot of pages dedicated to Italy. ${ }^{28}$ Bisaha suggests the text can be interpreted, with the Ottoman advance in mind, as

for instance, pp. 209-218. Moreover, see Harvey, The Hereford World Map, and Baumgärtner and Kugler, Europa im Weltbild. For more particular ideas about the frontiers, the end of the world and time, see Schmieder, 'Edges of the World', with its literature in note 2, and Von den Brincken, Fines Terrae. See also Von den Brincken, 'Descriptio Terrarum', for cartographic representations in Germany.

26 For this work, see especially Meserve, 'From Samarkand', pp. 17-18, 22, 24-25 (quote), and 31; Casella, 'Pio II tra geografia e storia', esp. pp. 43-46, 50-63, 66-72. For more in general, see Gebel, Nikolaus von Kues; the introduction by Nancy Bisaha in Piccolomini, Europa, pp. 10 and 35; Meserve, Empires of Islam, pp. 79-80, 96-104, 113-116, and 220-222. For the complaint against the barbarian character of the Turks, see Bisaha, Creating East and West, pp. 43-93, for eschatological elements, see pp. 139-161; the best recent work on the planned crusades against the Turks is: Weber, Lutter contre les Turcs.

27 Gebel, Nikolaus von Kues, pp. 12, 16-18, 32, 35, 39, 43, 45, 48-66; Oschema, Bilder von Europa, pp. 299-310.

28 The quote is from the Introduction to Piccolomini, Europe. For the work itself, the idea of Europe, and Piccolomini's intentions and sources, see especially the Introduction to this translation by Nancy Bisaha, pp. 3-5, 10-35. For Aeneas and the description of Germany, see Tewes, 'Zwischen Universalismus', pp. 54-56. Further, with attention to other works like Aeneas's De Boemia and De Germania, see Voigt, Italienische Berichte, pp. 127-153, and Baldi, 'Enea Silvio Piccolomini', esp. 
an exhortation to Christians to view themselves as part of a cultural, religious, and geographic collective, even as it acknowledges the diversity among its peoples. [...] What Western Christians most urgently needed to do was unite strongly enough (and long enough) to defend their common boundaries - a strikingly modern message. ${ }^{29}$

Both authors were also theorists of power, however, be it imperial, conciliar, or papal in character. Cusa even saw a crucial role for consent and underlined the importance of a correct elective procedure. ${ }^{30}$ Their ideas on the Christian world (or Europe), and its relation to other parts of the globe show, nonetheless, a framework or notion of territory that is completely different from the secular concepts used by Elden. ${ }^{31}$ Instead of sovereignty over a specific territory, it has to do with an idea of Christian unity. Both of them draw upon, and toy with, concepts of borders and boundaries under threat, although there is certainly a notion of superiority and a feeling of 'us versus them' in the work of Pius. The latter becomes clear when we consider Pius's use of the classics and his use of the civilised/barbarian dichotomy. Apart from these rather fluid abstractions of a Christian world and the boundaries of a Christian Europe, the world, both physically as well as mentally, could also be divided, in a practical sense, into a societas christiana and one composed of the 'others', that is, non-Christians. This conception

pp. 667-678, with a quote from Denis de Rougemont on p. 619: 'Dans sa Cosmographie générale, il le décrit comme un ensemble humain et historique, non plus seulement géographique, dont il détaille les conditions ecclésiastiques et politiques, économiques et sociales, nous dirons aujourd'hui: culturelle au sens large.'

29 Piccolomini, Europe, pp. 15-16, and 31-35 (with her earlier suggestion that Europe in combination with Asia 'helped shape an ideology of cultural unity and superiority to the East'). See also Baldi, 'Enea Silvio Piccolomini', pp. 672-674, and this passage on p. 673: 'L'Europa [...] si identifica chiaramento con la Christianatà: la Christianità è in Europa, e si potrebbe dire, solo in Europa, tanto che in I confini religiosi coincidono ormai con quelli europei.' For the idea of Europe, and Cusa's place in it, see Karageorgos, 'Der Begriff Europa'.

$3^{0}$ On the ideas of Piccolomini (mainly in some of his letters and in his Commentaries), see Schmidinger, Romana regia potestas, pp. 16-24 ('Rahmen für eine saekularisierte Idee des Imperium staatsrechtlich-politischer Prägung'); O'Brien, Commentaries, esp. pp. 88-98 and 156-188, and this passage on p. 181, for example: 'Here, it is not the papacy's right to temporal rule that Pius is defending specifically. Instead it is a much broader claim to ecclesiastical rule: priests make excellent princes - better ones, in fact, than do laymen.' For Nicholas of Cusa, see Watanabe, Political Ideas, especially chap. 4; Moritz, 'Concordantia als normatives Prinzip'; Oakley, The Watershed, pp. 200-204.

31 For Cusa as a sponsor or creator of maps ('Cusanus-type') and his relation to the Eichstätt Map of 1491, see Möller, 'Cusanus als Geograph'. Further, see Von den Brincken, 'Descriptio Terrarum', pp. $25^{-28}$. 
formed the basis of the ecclesiastical administrative division of the world, with Christian dioceses under an acting bishop, on the one hand, and, on the other, the so-called in partibus infidelium bishoprics, those territories or dioceses that had been catholic Christian once, but were now in the hands of unbelievers, especially Islam. Time was not crucial here: once a territory was Christian it remained a Christian territory forever. The idea of Christian versus non-Christian was all prevailing once again, just as there was a clear boundary between regions with their separate beliefs.

Additionally, aside from this larger administrative geographical distinction, a similar idea, based on a concept of natio, divided the later European Church proper. Just as the medieval universities divided their students into categories like the natio anglicana, so late medieval prelates thought and worked with concepts such as the Gallican, the English, or the German Church. The Reform Council of Constance (1414-1418) divided the clerical participants into four (later five) nations in an effort to avoid a misrepresentation in votes caused by a surplus of Italians present..$^{22}$ Although these types of nations are usually, in a somewhat loose and malleable form, connected to royal power, exemplified in the several concordats between popes and kings in the fifteenth century (like the concordat with the German nation in 1448), they might also imply a communitarian feeling and the fate of all the clerics in a certain region. An example of this is Aeneas Silvius's tractate Germania, directed against a complaint of his learned German friend Martin Mair about the exploitation of the German Church and nation by the Curia. 33

32 There is an abundance of literature on the complicated concept of natio; see, for instance, with many bibliographical references, recently Krah, "Natio", nicht Nation?' For the role played by 'nations' at universities, see, for example, Kibre, Nations. From the many recent discussions of the Council of Constance, see Swanson, 'Gens secundum cognationem'; an older treatment in Finke, 'Nation'. For the relation to modernist approaches, see Hirschi, 'Humanistische Nationskonstrukt'. For the connection between the nation at the university and at the councils, see the older treatment in Hay, Europe, pp. 75-83, and the recent Hirschi, Origins of Nationalism, pp. 78-88. For the different clerical views and divisions, see Oschema, Bilder von Europa, pp. 367-39o. One of the oldests maps (1357) records the division between the English and the Picardian nation at the University of Paris: Van der Krogt, 'Lokale kaarten', pp. 31-32.

33 For the difficulties in ranging nations and dioceses for research, see Tewes, Römische Kurie, pp. 6-18; for the difficulties in grasping the extent and organisation of the Church, see Schmidt, 'Raumkonzepte', pp. 99-105, and Tewes, 'Das spätmittelalterliche Papsttum', pp. 605-6o9. In general, for the Roman idea of the christianitas, see Schmidt, 'Raumkonzepte', pp. 105-120, and Tewes, 'Zwischen Universalismus', esp. pp. 46-47, and for borders p. 43, note 31. See also Mazel, L'évêque et le territoire, pp. 359-363. For Martin Mair and the epistolar reply of Piccolomini, see Piccolomini, Deutschland; Watanabe, 'Imperial Reform'. I could not obtain a copy of Claudia Märtl's recent article on Piccolomini and Mair. 


\section{Ecclesiastical territory}

With parishes and bishoprics, we tread on more solid ground, although the concept of frontier and boundary becomes clearer only in time. With the advent of a more modern geography and mapping, and its combination with the formation of states, we have become used to thinking in clear lines from A to B, separating different territories by boundaries. ${ }^{34}$ Ronnie Ellenblum presents a different picture of Crusader Palestine, containing centres and core settlements such as castles, with their influence and effectiveness fading and dissolving into more vague, disputed borderlands without any clear demarcations, natural features notwithstanding. ${ }^{35}$ The same is true for the ways these lands are held, sometimes in fief, sometimes as an allodium, and anything in-between, without the necessity to assemble them all in a contiguous territory, often with multiple rights by more than one person at the same time, again without the necessity to be constricted to one, well-defined area.

A similar background can be seen in the development of parishes and their territories. For a long time, parishes and their origins were presented, with a cartographic mentality, as contiguous territories clearly delimited by boundaries. ${ }^{36}$ From a clerical viewpoint, however, the parish (parochia) was originally formed not by space but by the faithful who dwelled together once in a while for services in a building or a location. ${ }^{37}$ Only growing pressure, from the need to raise tithes and other income for the priests or their institutions, and other legal incentives from bishops and dignitaries, and the integration of cemeteries and houses into the surroundings of the church building, resulted in a growing 'territorialisation' of the parish,

34 See Ellenblum, 'Were There Borders?', pp. 105-109 and 118; for the problems associated with the concept of frontier, in general, see the lucid introduction of Abulafia, 'Seven Types of Ambiguity', esp. pp. 1-6, 10-16 (for political frontiers). Furthermore, see Aydoğan, 'Changing Perceptions', p. 30: 'Geographers and political scientists consider frontiers and boundaries as belonging to distinct categories: Frontiers are zones evolving organically between states or societies; boundaries, on the other hand, are state-defined artificial lines of separation. Although this definition of "frontier" is of considerable importance for modern conceptualizations, it cannot be easily applied to premodern frontiers.'

35 Ellenblum. 'Were There Borders?', pp. 109-117.

36 A good example is the work of Michel Aubrun, La paroisse, with a ninth-century example from the Corrèze on pp. 199-200; see also p. 204. For an older overview of ecclesiastical organisation and canon law, see Feine, Kirchliche Rechtsgeschichte, pp. 402-427. For all the problems and regulations regarding Eigenkirche, see Wood, Proprietary Church.

37 Lauwers, 'Paroisse'. 
which historians newly interpret as a special spatial entity. ${ }^{38}$ In southern France this evolution transpired mainly from the end of the ninth to the twelfth centuries, sometimes earlier in the tenth century and elsewhere more than a century later. ${ }^{39}$ This can be observed occuring in other places, too, exhibiting regional differences and accents. Generally speaking, a web of interlocking, contiguous parishes with fixed boundaries and territories covered all of Europe in the Later Middle Ages. ${ }^{40}$

In parts of the Prince-Bishopric of Utrecht earlier domanial structures influenced the formation and the territory of parishes, while pre-existing archdeaconries were another formative factor. The reclamation of peatbogs and other lands, with their man-made or natural features such as ditches and watercourses, was a final element in the determination of boundaries and territories. ${ }^{41} \mathrm{~A}$ recent reconstruction of the parochial structure in Frisia led to the remarkable conclusion that the tenth and eleventh centuries showed a spectacular growth in the number of parishes, often all equally spaced and integrated into older structures, probably a planned development under the direction of the bishops and their administrators. ${ }^{42}$ According to

$3^{8}$ I am not delving here into lexicographic problems such as the difference between space and territory nor in mental spatial images and the flood of literature on this topic over the last couple of decades.

39 For the parish in general, see the excellent Iogna-Prat, La Maison Dieu, pp. 176-182, 229-249, 294-306. For this territorialisation and its cartographic expression especially: Hautefeuille, 'La cartographie de la paroisse', and Hautefeuille, 'La délimitation'. For the crucial input from the material world: Zadora-Rio, 'L'historiographie des paroisses', and in connection with burial places and churchyards: Zadora-Rio, 'The Making of Churchyard and Parish Territories'. For the somewhat different development in England: Blair, 'Recherches récentes', and Blair, The Church in Anglo-Saxon Society, pp. 368-504, esp. pp. 369-370 and 422-425. Fundamentally, see Lauwers, 'Paroisse', passim; Lauwers, Naissance, pp. 24-30, 49-54, 85-88 and 137-151. For the later situation in the German Empire, see the work of Enno Bünz, e.g. his 'Pfarreien und Pfarrgemeinden', esp. pp. 30-39 underlining all the differences between the parishes. For different types of churches: Janssen, 'Differenzierung der Pfarrorganisation'.

40 See Schmidt, 'Neugliederung', p. 107, for the importance of the Fourth Lateran Council of 1215 here.

41 Dekker, Kromme Rijngebied, pp. 279-361, esp. pp. 333-347 (boundaries identical with the reclamations).

42 De Langen and Mol, 'Church Foundation', with a recapitulation on pp. 49-52, using archaeology, GIS mapping, and an extensive historical documentation. See also their footnotes 1, 9, and 98 for references to the other literature on the formation of parishes in most of the Low Countries. Elisabeth Zadora-Rio coordinated a similar project for the Touraine. I was unable to get a copy of her edited volume, however. For an extensive review and interesting responses and debate, see Noizet, Rodier and Zadora-Rio, 'Débat', esp. pp. 7-11 and 18-21. A preliminary reconstruction of similar developments in Holland, again with an important role for the bishop and a growing territorialisation since the middle of the tenth century, is De Langen and Mol, 
Kuys, parochial boundaries (often) coincided with the territories of secular jurisdictions in the northern Low Countries, in general. ${ }^{43}$ Inside towns, the boundaries between parishes could be very explicit. In Utrecht, for example, we can follow them from street to street, sometimes even mentioning specific houses as a limit, like '[...] unto the cornerhouse called The Coffin opposite the house The Dappled Horse'. ${ }^{44}$ Fiscal registers like the Hofstedengeld of c. 1397 from Gouda (Holland) make use of a similar system, describing street by street the owners of taxable houses. In the register of 1405 , from the same town, levies for the militia run for 37 districts from certain houses in a street to other particular houses. On a lower administrative level, clerical and secular authorities drew upon the same idea of delimitation of territory with its fiscalisation and jurisdiction. ${ }^{45}$

The boundaries between villages and thereby frequently also between lordships and principalities were expressed in manifold ways, often by using the boundaries between parishes; they probably even did originate in them partly. ${ }^{46}$ These boundaries between parishes were fairly strict and well known because each man had to know where he ought to confess and where he was expected to be married and, later, to be buried. In one of a series of border disputes between the county of Holland and the Prince-Bishopric of Utrecht, spies from Holland referred to parishes and their boundaries as demarcations between these principalities in $1525,15^{26}$, and 1527 . They also used roads as points of reference, just as the location of censual lands and lease lands. Ditches and trenches were searched for, just as was the location of a fortified house, certain bushes and trees, and a mill. Other points of reference were the Cathedral Tower miles away and an important boundary sign, the so-called blauwe zerk, probably a bluish-black hardstone. (This was hidden under water in a ditch, something which made the reconnoitring party open sluices during the night, under constant threat from a loudly

'Kerk, macht en ruimte', esp. pp. 267-268 and 271-272, more extensively dealt with in De Langen and Mol, 'Church, Landscape and Power'.

43 Muller, De indeeling van het bisdom, pp. 107-120, esp. pp. 116-119: for Frisia a complete overlap; elsewhere not automatically; however, see Kuys, Kerkelijke organisatie, p. 44; Robinson, Beneficed Clergy, p. 2. See, however, Leturq, 'Territoires agraires' for the too simple equilisation of parishes and agrarian structures.

44 Muller, De indeeling van het bisdom, p. 255-256: '[...] teghen over het Vleyshuys ende enighe huysen voerby tot het hoeckhuys genaemt de Doodkist, teghens over het Bontepeert [...]". For two important French towns, see Comte and Grélois, 'La formation'. For Tours, see Noizet, 'De l'église au territoire'.

45 Het Goudse hofstedengeldregister, pp. lxxv-lxxxii, 1-13 and 27-29.

46 A complication being a situation of dual lordship or the division of a parish between two principalities, for example, Maastricht or Wegberg in Germany. 
barking watchdog whom they unsuccessfully tried to pacify with bread.) Other markers included the Leeuwenpaal (Lion's Post) of 1356 and a whole range of piles and posts. ${ }^{47}$ The Hollanders also made good use of maps; the oldest one dated from 1472 although some of them had been newly made to argue their case. They also talked to several priests, researched foundation charters in churches, checked memorial registers, tried to pick the memory of the 'oldest and richest man' in the area, and asked other men 'to which church they belonged' (ter kercke hoerden). Parochial boundaries were clearly conclusive here and they show us how much they were integrated into a more general idea of territory.

In addition, parishes gave an organisational structure to the work of couriers and messengers of bishops, archdeacons, ecclesiastical judges, the estates, and lords. Not only did the collectors of papal and other clerical subsidies use parishes and their territories as defining elements in their fiscal administration, but secular lords did the same. Cartularies and the administration of leases and lands, etc., were likewise organised by parish, just as much in clerical as in secular organisations. ${ }^{48}$

Apart from parishes, other ecclesiastical entities were relevant to the life of medieval Christians. Archdeaconries, often divided into several deaneries, were formed out of a number of parishes. ${ }^{49}$ Their boundaries were usually based on those of the parishes, although new parishes sometimes crystallised within a pre-existing archdeaconry, constricted or delimited by its boundaries. Part of the ecclesiastical jurisdiction of bishops had been delegated to the incumbents of these archdeaconries and their dependent deaneries. In the bishopric of Utrecht this entailed a large part of the supervision of the clergy, but also the correction of laypeople who broke canonical rules. Examples include bigamy, sexual delinquency, gambling, and debt litigation, but the ban on working on Sundays and feast days was most often mentioned in the juridical registers..$^{0}$

47 These and the following examples from Zestiende-eeuwsche wandelingen, pp. 15-20, 22-23, 25-27, 35-37, 46-54, 57-58. For the maps: Enklaar, 'Oudste kaarten'; Groeneveld, 'Oostgrens van het Gooi'; Van der Krogt, 'Lokale kaarten', no. 7, pp. 34-35.

48 Muller, De indeeling van het bisdom, pp. 5-39, 259-263, 323-326; Bronnen voor de geschiedenis, pp. 12-20, 52-55, 146-151; Van den Hoven van Genderen, 'Registers', pp. 179-184. See also Mazel, L'évêque et le territoire, pp. 338-343.

49 Dekker, 'De vorming van aartsdiakonaten'; Bijsterveld, Laverend, pp. 35-46 with the literature cited there; De Moreau, Histoire de l'Église, pp. 91-102; Lambrecht, Parochiale synode, pp. 192-204, 210-219, 255-259; Kuys, Kerkelijke organisatie, pp. 128-149; Mazel, L'évêque et le territoire, pp. 308-315. $5^{0}$ See esp. Van Moolenbroek, 'Zeeuwen in verzet'; Bijsterveld, Laverend, pp. 39-40; Lambrecht, Parochiale synode, pp. 255-259. 
The diocese was the ecclesiastical organisational system on a higher level. Just as the parish was based on the congregation of a certain number of souls, so the bishopric grew out of the aggregate of a certain number of parishes, encompassing all kinds of other inheritances and influences like the Roman civitas or the pagus. ${ }^{51}$ Just like parishes and archdeaconries, bishoprics became gradually territorialised. In England, and probably in France, too, this process had ended in the twelfth century. $5^{2}$ The same holds true for the Low Countries, where the borders of the bishopric of Utrecht were mainly and roughly formed by the (old) courses of the Meuse and Waal/Rhine rivers. Due to the presence of extended and unreclaimed peatbogs, the boundaries between the bishoprics of Utrecht and Münster were less well defined at that time. ${ }^{53}$ Where borders were not determined by the geography, as in the eastern part of Zeeuws-Vlaanderen, dikes played a part. Parishes were 'traded' here between the bishops of Utrecht and Tournai to solve their boundary disputes, just after the middle of the thirteenth century, at a time when several Utrecht ecclesiastical organisations tried to reorder or to rescind their Fernbesitz, their far-off landed properties and rights, in Flanders or elsewhere. ${ }^{54}$ As was the case with parishes, deaneries, and archdeaconries (although enclaves certainly existed), the bishoprics had a fixed, finally contiguous territory. In it their bishops were responsible for the welfare and the correct functioning of their clergy, just as much as for the souls of the faithful. Preaching and exhortation were one part of

$5^{1}$ Iogna-Prat, La Maison Dieu, pp. 48-62, 83-98, 205-220, 249-257, 405-422; Claeys-Bouuaert, 'Évêques', pp. 570-571; Feine, Kirchliche Rechtsgeschichte, pp. 35-46, 54-56, 97-100, 125-127, 182-205, 213-218; Rapp, Holy Bishops; Patzold, Episcopus; Haarländer, Vitae episcoporum.

52 Swanson, Church \& Society, pp. 1-6, rural deaneries often 'coterminous with hundreds and wapentakes'. For France, see the brief remark in Mazel, Féodalités, pp. 363-364. See also Iogna-Prat, La Maison Dieu, pp. 216-220, 310, and Klueting, Klueting and Schmidt, Bistümer und Bistumsgrenzen. For an in-depth view, see Mazel, L'évêque et le territoire, pp. 221-227, 233-235, 237-244, 256-264 and 271-274.

53 Kuys, Kerkelijke organisatie, pp. 30-31. An example from a completely different region: Schmidt, 'Neugliederung', p. 115. For a map of the archbishopric of Cologne: Burkhardt, Mit Stab und Schwert, pp. 638-639; detailed information in Janssen, Das Erzbistum Köln, pp. 31-52, and map 3 and 4 . For the borders of the bishopric of Liège: Bijsterveld, Laverend, map 1.1 and pp. 27-28. Rivers and watercourses are in part formative here. For the other dioceses of the Low Countries this is sometimes harder to assess. See the map in Dierickx, De oprichting, p. 348. The river Schelde was decisive in the boundaries between Cambrai and Tournai, just as elsewhere the Scarpe and other watercourses like the brook La Chaudière influenced the formation of other boundaries. Landed property, and especially the dotation with domains and rights, and the interplay with the older civitates, pagi and younger principalities were prime moving factors probably too. See the discussion by J. Deharveng in De Moreau, Histoire de l'Église, pp. 31-45.

54 Van den Hoven van Genderen, “'Utrechtse Vlamingen”', pp. 154-160. 
their task; administration and jurisdiction, the application of the rules of canon law for all the inhabitants of the bishopric, were another part of it. ${ }^{55}$

\section{The new bishoprics of 1559}

Bishopric and parish borders usually remained fairly stable for centuries, sometimes even up to the present. ${ }^{6}$ The Low Countries are one of the important exceptions to this rule. ${ }^{57}$ When Philip II (r. 1555-1598) forced all involved parties to accept the creation of new bishoprics in 1559 , it completely reshuffled the older ecclesiastical division. It is therefore interesting to investigate why these new bishoprics were deemed necessary and whether new organisational principles were drawn upon for this new division.

The effort of kings and princes to control (or better regain control of) the clergy in their lands was an important political factor from the twelfth century onwards. This resulted in a lot of debates and conflicts, and in the development of new theories on the extent of royal and ecclesiastical authority. Robert Swanson characterises the situation for England as 'two laws, one kingdom', without, however, any suggestion of a constant tension between church and realm..$^{58}$ In general, there were two main points of conflict which traditionally had a territorial character, namely taxation and jurisdiction. Another general trend was to limit papal influence and intermingling, chiefly by following the notion of ecclesia gallicana or anglicana, under which bishops and clergy mainly collaborated with or were subservient to

55 Patzold, Episcopus; Haarländer, Vitae episcoporum; Van Rhijn, Shepherds of the Lord. See also Schmidt, 'Neugliederung', pp. 107-113. Some monasteries, clerics, or orders were exempted by a papal privilege, just as some cases were reserved for the judgement of the pope, but in general almost everybody was in some way subjected to episcopal supervision. In general, see Mazel, L'évêque et le territoire, pp. 318-335. Earlier in his book Mazel discussed enclaves and exemptions. 56 For many changes of earlier boundaries in France (and in the German Empire through the creation of Magdeburg, Bamberg, and the eastern bishoprics): Mazel, L'évêque et le territoire, pp. 182-215, 274-285, and 356-359, and Klueting, Klueting and Schmidt, Bistümer und Bistumsgrenzen, esp. Schmidt, 'Neugliederung', pp. 108-114, for the continuity of the boundaries of dioceses after 1215 .

57 Of course, there were other exceptions. Somewhat comparable with Utrecht, and also motivated by a concern to combat heresy, is the south of France in the beginning of the fourteenth century: Schmidt, 'Neugliederung'. During the Henrician reorganisation of 1540-1542 several 'cathedrals of the New Foundation' were established in England, with the use of some of the largest dissolved monasteries like Peterborough. The size of Philip's changes in 1559, with three new archbishoprics, each with new bishoprics, is on another level, and has also a different background than the English example.

$5^{8}$ Swanson, Church \& Society, pp. 140-190. 
the king. Concordats with the pope were one of the ways to lessen strains and disputes and to achieve greater royal control over churches and clerics. ${ }^{59}$

One of the earliest attempts in the Low Countries to change the ecclesiastical status quo dates to the government of Duke Jan III of Brabant (r. 1312-1355) in the 1330s. Since the Duchy of Brabant was divided between the two dioceses of Liège and Cambrai, he tried to get permission for the creation of a separate Brabantian bishopric. He claimed, amongst others, that the two bishoprics were too large to be managed effectively, and that the rites differed in both dioceses. ${ }^{60}$ The count of Holland seems to have had similar plans for the creation of his own bishopric in the beginning of the fifteenth century. ${ }^{61}$ Less questionable than the count's initiative were the plans of Charles the Bold (1467) and especially those of Maximilian of Habsburg (1483) to split the diocese of Liège in order to create new bishoprics in, for example, Leuven and Namur. Maximilian underpinned his case by recalling the vastness of the bishopric of Liège, its wealth, the two languages spoken there, and the fact that it covered multiple principalities. $^{62}$

The plans of Charles V carried more weight, however. They had their origin in the beginning of the 1520 s and were finally formulated in a plan presented to the pope in 1525 . At that time Charles was not yet lord of the north-eastern parts of the Low Countries. Six new bishoprics were proposed: in Leiden (Holland), Middelburg (Zeeland), Brussels (Brabant; Cambrai would keep its francophone parts), Ghent (added in 1530 for the Flemish parts of Cambrai), Bruges (the Flemish territories of Tournai), and Ypres (the Flemish territories of Thérouanne). ${ }^{6}$ The plan was suddenly, and rather unexpectedly, dropped in 1530 .

The impetus for the decisive plan for the creation of new bishoprics in 1559 came from Franciscus Sonnius (1507-1576), a former professor of theology

59 From the classic expositions of Joseph Strayer and Walter Ullmann over biographies as Jean Favier's Philippe le Bel and Enguerran de Marigny, and the whole literature on the Western Schism and the conciliar movement. More recent work often highlights, and problematises, the cooperation of clerics with the state; see, for example, Barralis et al., Église et État, Église ou État? For political thought, see the last two volumes of Oakley's magnum opus.

60 Fairon, 'Un projet de démembrement', esp. pp. 147-157; Dierickx, De oprichting, pp. 27-28; Dierickx, Documents, vol. 1, pp. 59-71. Compare with Schmidt, 'Neugliederung', p. 114 for the argument of a 'zu große Ausdehnung' of a bishopric, and the concern for the care of souls.

61 Dierickx, De oprichting, p. 29, contrary to Jongkees, Staat en kerk, p. 16.

62 Dierickx, De oprichting, pp. 30-31.

63 Dierickx, Documents, vol. 1, pp. 76-96; Dierickx, De oprichting, pp. 32-37. For a summary of Dierickx and the history behind the new dioceses, see Weis, 'Hierarchie'. For the contemporary plans of Cardinal Wolsey, see Swanson, Church \& Society, p. 2. 
and rector of the University of Leuven, cathedral canon in Utrecht, and inquisitor in Holland, Utrecht, and Guelders (1545-1557). Sonnius attended the Council of Trent two times as one of the representatives of the bishop of Cambrai. During the sessions of $151^{1-155^{2}}$ he devised a kind of masterplan for the division of older bishoprics and the creation of new ones. ${ }^{64}$ His main motive was to impede the growth of Protestantism in the Low Countries; his main objective was the creation of smaller dioceses, all under the aegis of the Habsburgs, with resident bishops, graduated in law or theology, and a cathedral clergy which was vitalised by the obligatory admission of a set of likewise trained new canons, who would also act as papal and episcopal inquisitors. A new system of remuneration would stimulate the residence of the clergy of these new cathedrals and its active participation in choir services. ${ }^{65}$ All in all, this was intended to result in a more active and effective defence of Catholicism. At the council Sonnius asked several prelates for information and discussed his ideas with them, with some of the cardinals present. He was also well aware that his plan, if supported, would be presented to the pope and his cardinals. ${ }^{6}{ }^{6}$

In his plan Sonnius proposed to create eleven or twelve new bishoprics, and two new church provinces with their archbishops at the apex. This was all to be at the cost of the existing provinces of Cologne and Rheims, and the dioceses of Cologne, Utrecht, Liège, Cambrai, Tournai, and Thérouanne (and less so Arras), all of which would lose large tracts of their territories and many subjects. Cologne would be compensated for its losses by the creation of a new diocese with its cathedral in Roermond, covering the area from Nijmegen southwards into Limbourg. This diocese would become a new suffragan of Cologne. The other bishops would receive annuities as compensation, as well as the landed properties of some important monasteries. Even better, with their reduced sizes, the affected dioceses would be able to improve the care of the souls of all their inhabitants, and who could complain about that? ${ }^{67}$

64 Dierickx (De oprichting, pp. 37-38; Documents, vol. 1, p. 151) still believed that the author was another inquisitor, Ruard Tapper. Since then, Postma has convincingly shown that the old attribution of the plan to Sonnius was correct indeed: Postma, 'Nieuw licht op een oude zaak', and Postma, Viglius van Aytta, pp. 83-85. The text of the plan is edited in Dierickx, Documents, vol. 1, pp. 107-151.

65 Dierickx, Documents, vol. 1, p. 145: 'ut saltem plurima oppida simul cum suis territoriis habeant unum episcopum unumque collegium doctorum virorum ad defensionem animarum suarum contra rapacissimos lupos undequaque irruentes'. On p. 127: half of the income of the canons would come from attendance fees for choir services.

66 Ibid., p. 112: 'Sanctissimus Dominus noster Julius et qui cum eo sunt Cardinales [...]".

67 Ibid., pp. 142-144. Compare with Schmidt, 'Neugliederung', pp. 114-118 and 120-122. 
Sonnius justified all these changes by recalling that no part of the Christian world was more populous than the Low Countries, dotted as these were with towns, castles, and villages, rich in trade and crafts - with the exception, however, of an adequate number of bishops. ${ }^{68}$ Furthermore, some of these bishoprics were situated partly outside the dominions of Charles V, with nefarious consequences due to the ever-ongoing wars of kings and princes. Sonnius noted that the bishopric of Utrecht contained no less than 2,080 parishes and circa 200 walled towns. He tried to devise its partition into five or six bishoprics, taking account of former principalities and existing regions, natural frontiers, and distances, but also of an idea of population density. He argued to the pope and his cardinals that Utrecht itself was more or less comparable to Augsburg, in population and circumference. Other towns like Amsterdam, Delft, or Gouda were much larger than Trent (c. 7,000 inhabitants); a number of others were comparable or (much) smaller. ${ }^{69}$ The town of Den Bosch was easily four times as large as Trent, and contained a school with over 1,00o pupils, maybe even double that number. ${ }^{70}$ More curious in our eyes was his justification for the creation of a bishopric in Zeeland, with its seat in Middelburg: this island was situated in the ocean, where the air is unhealthier and the smell of the sea is more repulsive to outsiders'. For that reason, it was more expedient if the inhabitants got their own bishop, a native of their region who could better stand the odour. ${ }^{71}$ Sometimes Sonnius used distances between towns (a two-day trip) or existing regions and borders, at other times he 'draws a straight line' to demarcate territories..$^{2}$ The word territorium itself is rarely used in this proposal, although Sonnius writes that the regions mentioned (like Holland) will have one bishop, who together with his clergy will take care of several towns and the surrounding

68 Dierickx, Documents, vol. 1, p. 108: 'nulla pars orbis Christiani aut populosior sit, aut frequentior oppidis, castris, pagis, negotiationibus, divitiis, nobilitate [...]”.

69 Ibid., pp. 109-113, with this on p. 112: "habent perspectissimam magnitudinem et qualitatem huius civitatis Tridentinae'.

70 Ibid., p. 132. Sonnius himself was born in Zon, in the vicinity of Den Bosch where he had been a pupil himself. In his study of Sonnius and all the criticism voiced against him, Goossens gives the average number of parishioners in these new dioceses as 150,000: Goossens, Franciscus Sonnius in de pamfletten, p. 47.

71 Ibid., p. 115: 'Et quia haec insula est in Oceano, ubi est aer insalubrior et odor maris exteris hominibus inconveniens, ideo expediret eos habere proprium episcopum ex ea regione assumptum, illiusque aeris bene patientem.' Sonnius might refer to the smell of drying and rotting plants or grounds during ebb.

72 Ibid., p. 113: 'usque ad rectam lineam trahendam a Munickhuysen prope Airnhem ad medium locum inter Amersfoert et Harderwijck [...]'. For distances, also p. 132; for a straight line, p. 133. 
'territories' under their authority. ${ }^{73}$ While the word 'territory' means the geographical zone of urban jurisdiction here, it is clear that the new bishoprics can be interpreted likewise as a type of territory, as dioceses with all of the earlier described criteria of borders, jurisdiction, fiscality, population, and conceptual coherence. ${ }^{74}$ For the design of the other dioceses, Sonnius used the same criteria, although he was less elaborate for Flanders. The rest of his plan was devoted to a project for an endowment of all these new bishoprics, mainly by the incorporation of (parts of) some of the grand old monasteries. The great advantage of this type of endowment for the emperor would be the huge reduction of costs; its political consequences were severely underestimated, but that is another story.

Sonnius's plan gained momentum the moment it got into the hands of Viglius of Aytta, president of the Secret or Privy Council, one of the most influential councillors and politicians in the Low Countries, and a close collaborator of Regent Mary of Hungary and Granvelle, the future cardinal and archbishop of Malines. ${ }^{75}$ From 1558 onwards Sonnius worked in Rome as a representative of Philip II, the new overlord of the Low Countries, to secure papal consent and support for the new bishoprics. Partly due to changing political circumstances, the pope finally solemnly promulgated the creation of the bishoprics on 12 May 1559 . Sonnius had received an extensive instruction for the reorganisation, signed by Philip himself, and presented the pope and his cardinals with all kinds of documents and several maps, decorated with coloured ribbons to indicate the new dioceses. A committee of several cardinals had approved the plans beforehand.$^{6}$ In the end, fourteen new bishoprics and three new provinces (Cambrai was added) were created.

On the advice of the committee of cardinals, Sonnius had added an explanation and justification to the decision of the committee. He stressed all the expenses the king had incurred with the Inquisition and with the creation of these new bishoprics. He mentioned that all their territories were part of the Low Countries. In another document the author clearly differentiated

73 Ibid., p. 145 .

74 See also Schmidt, 'Einleitung', p. 12: ‘[... er blieb wirksam und förderte eine räumlich struktierte Kompetenzdefinition, welche sich auch als Präfiguration moderner Staatlichkeit erweisen konnte. Vor allem verknüpften die Bistümer die Beziehungen der Menschen innerhalb konkret erfahrbarer Kontakte des Alltagslebens mit einer umfassenden Großorganisation, deren Wirkung den Horizont des Einzelnen überschritt, ihn an eine idealiter die Menschheit umfassende Kirche und Christenheit anband. [...]'.

75 Postma, Viglius van Aytta, pp. 84-86.

76 Dierickx, De oprichting, pp. 45-59; Dierickx, Documents, vol. 1, pp. 171-174, 178-207; Postma, Viglius van Aytta, pp. 168-172; the advice of the Committee of Seven Cardinals is edited by Jansen, 'Het advies', pp. 3-22; the papal bull by Brom and Hensen in Romeinsche bronnen, pp. 69-74. 


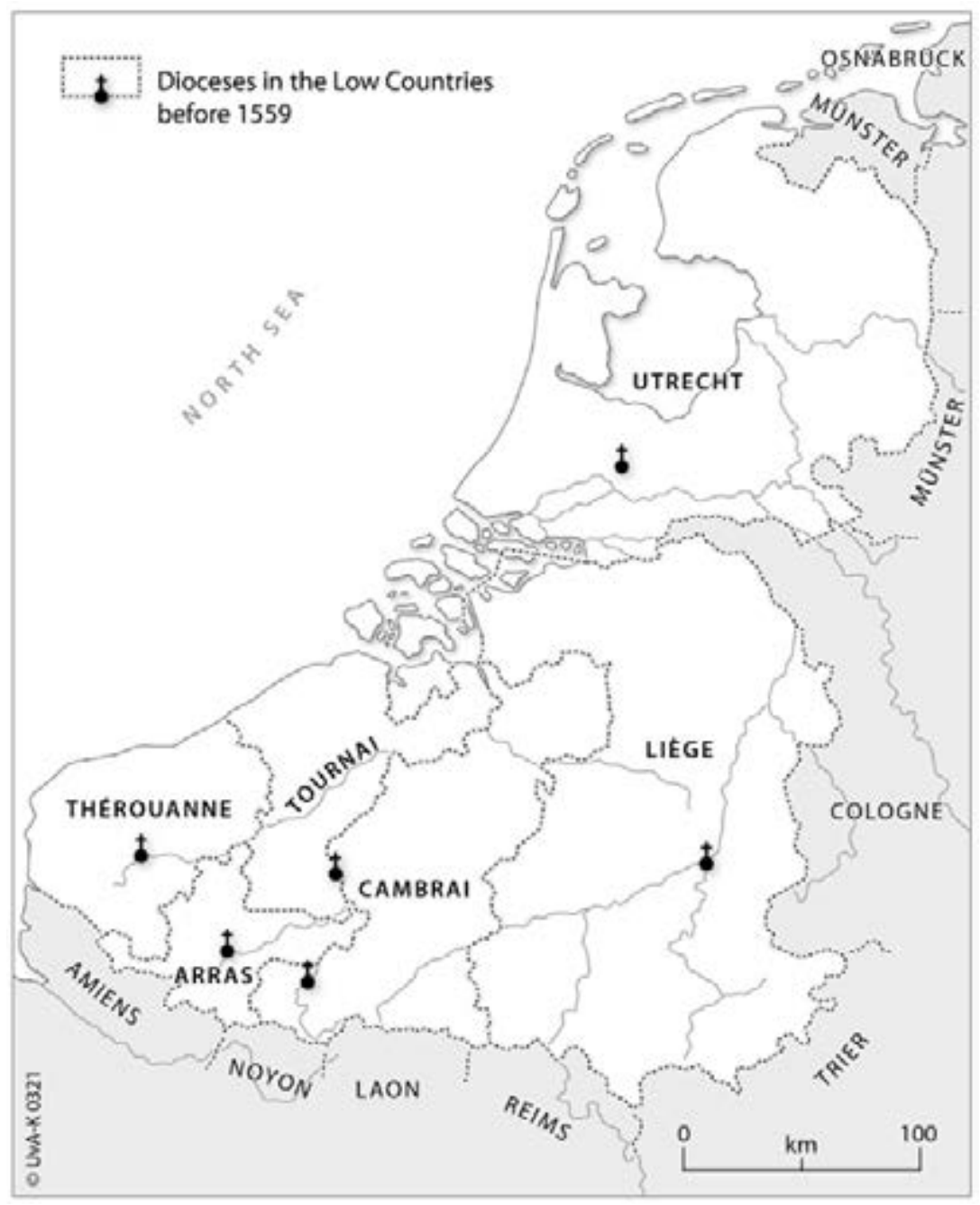

Fig. 3.1. Map of the dioceses in the Low Countries before 1559. Source: UvA-Kaartenmakers, on the basis of a design by Hans Erens. WikiCommons Low Countries Medieval Dioceses.

between Flemish-speaking lands and dioceses and francophone ones. ${ }^{77}$ In still another one the magnitude of the dioceses was given with their length and breadth (for example, 69 Italian miles by 40 miles for Utrecht), and the number of their towns. ${ }^{78}$ In the final bull all these elements return, the diocesani linguae idiomate, the boundaries of Philip's dominions (intra 


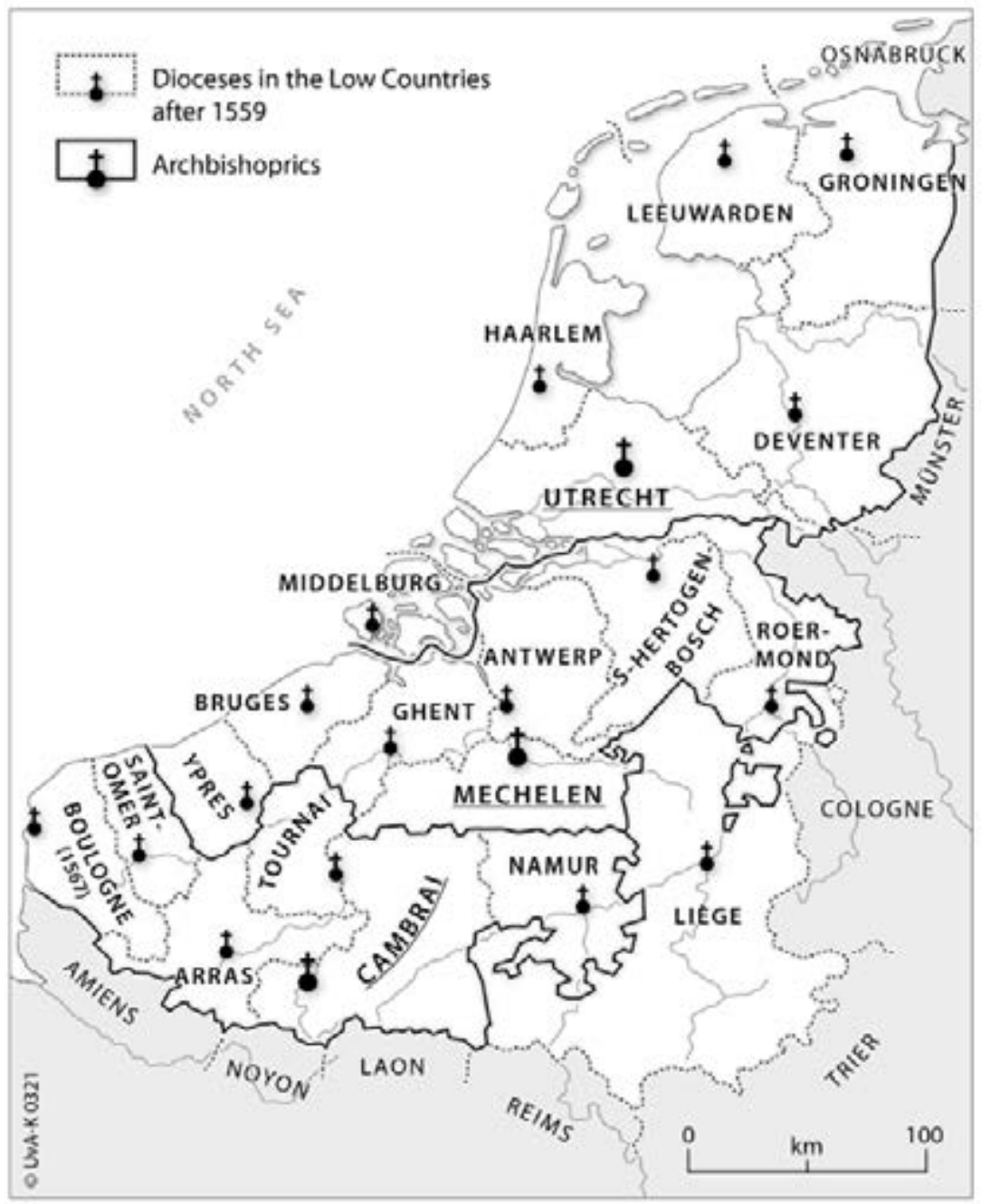

Fig. 3.2. Map of the (arch)dioceses in the Low Countries after 1559. Source: UvA-Kaartenmakers, on the basis of a design by Hans Erens. WikiCommons Super Universas Dioceses.

fines Philippi regis), natural frontiers like the river Waal (=Rhine), and the dimensions and towns of each diocese. ${ }^{79}$ In response to the proposal of Sonnius, the pope had ordered a committee of five (which consisted, among others, of Granvelle, Viglius, and, later, Sonnius) definitively to settle the territories of the new dioceses and their endowments. Almost all dioceses were described by an enumeration of oppida et villagia sive pagos, although 
for Saint-Omer and Ypres the churches and parishes of each town, in their respective deaneries, were listed. Both systems were probably identical, so that a village coincided with its parish. ${ }^{80}$

All in all, most elements and motivations in these plans were not new. For instance, the wish to let a diocese correspond with (a part of) a principality can already be found in reform proposals for Flanders circa 1300. Another example concerns the idea of natural borders, and the wish for smaller dioceses with a reformed, learned, and resident clergy. The criterion of language to separate bishoprics is equally important. However, this principle had already been drawn upon after the Battle of the Golden Spurs of 1302, when the Flemish supplicated the pope to remove the Walsce (francophone) bishops and to create new bishoprics. ${ }^{81}$ More important than mere politics here was canon law, which required that each parish priest be able to preach and converse in the native language (idioma). Border maps were at least a century and a half old or more. However, the combination of population density, distances, natural borders (or just straight lines), language as a demarcation, political unity, and the correspondence between ecclesiastical and political unity, plus the new purpose of defence against heresy, was a potent one. According to the geographer Herman van der Haegen, it was even a first attempt to create a new spatial, rational, administrative, and hierarchical division of the Low Countries. ${ }^{82}$ North of the 'great rivers' we find the northern Low Countries with Utrecht as archbishopric; south of it a 'Flemish space' for the non-francophone southern Low Countries (with Malines), and furthermore the francophone southern Low Countries minus the independent Liège (with Cambrai). ${ }^{8}{ }^{8}$ The new dioceses reinforced existing identities; for Van der Haegen it was the start of a tripartite division of the Low Countries, and the first acknowledgement of the Flemish-speaking Low Countries as a unified spatial and ecclesiastical entity. ${ }^{84}$

80 Dierickx, Documents, vol. 1, pp. 223-224 and 266-302. For the endowment, see pp. 506-526. Compare with Schmidt, 'Neugliederung', pp. 114-116 and 122-124.

81 Dierickx, De oprichting, pp. 26-27. In the decision of the Committee of the Seven Cardinals in 1558 or 1559 for instance: 'Postremo quia diversitas idiomatum est inter Remenses et plerasque ecclesias per Flandriam erigendas, atque tanta distantia, ut novem dierum itinere opus sit, priusquam Remensis ecclesiam adeatur [...]'. On language as a decisive factor, see also: Schmidt, 'Raumkonzepte', pp. 121-124, although he mentions canonical objections.

82 Van der Haegen, De eerste Vlaamse ruimte, p. 34

83 Ibid., pp. 42-48 and 52-56.

84 Ibid., pp. 57-61. Van der Haegen's grand concept is, however, liable to critique in its discussion of the historical dimension of modern terms. 


\section{Conclusion}

Parishes grew out of the need to take care of the souls of people. The scale of this care was, just as much in the Later Medieval period as in the early modern one, described as a particular number of 'souls': a curate had to take care of a certain number of souls or his parish numbered a stated number of souls. The parishes, or more correctly for the earliest period, their parish churches, formed the basis of dioceses. A diocese consisted of a number of parishes. Usually, the boundaries of parishes determined the boundaries of dioceses. From the Later Middle Ages onwards we have a system in which people identified themselves with their parishes. ${ }^{85}$ They also carried all kinds of fiscal and monetary obligations, in the form of the upkeep of the church building, the remuneration of the clergy, and the payment of tithes and taxes to bishops, cathedrals, archdeacons, and so on. Legally, they were subjected to a whole hierarchy, from their own parish priest to the archdeacon, bishop, archbishop, and finally to the pope and his auditors and penitentiaries. These clerical leaders made elaborate use of canon law, expressed in diocesan statutes, in edicts, and in all kinds of verdicts. Finally, there was a clear idea of boundaries and contiguous territories, albeit with disputes and their resulting adjustments. Distances and population density mattered, too. Finally, the vernacular language was another formative factor. With Dominique Iogna-Prat, we can succinctly summarise the Church as an 'institution totale'. ${ }^{86}$

All in all, we have all the criteria and conceptual tools here that Elden stipulated: territory, economy, law, population, identity, and even, in a way, sovereignty and supremacy, not just as vague ideas, not only in practices, but clearly delineated and integrated into a complete ecclesiastical structure and mindset. ${ }^{87}$ One wonders why Elden chose to concentrate on 'political technology', and looked for it only in the theorists of temporal power and the great names of Western political

85 For instance: Duffy, Stripping of the Altars, pp. 131-154; Duffy, Voices of Morebath; Bogaers, Aards, betrokken en zelfbewust, pp. 179-346 and 371-492.

86 Iogna-Prat, La Maison Dieu, p. 309, in a preliminary conclusion under the heading 'une première territorialité chrétienne', describing the end of a development between c. 800 and c. 1040, with l'emergence de l'Église comme “institution totale", comme "corps" destiné à inclure l'ensemble de la société'.

87 See also Schmidt, 'Neugliederung', p. 107: 'Die verfaßte Kirche imitierte das römische Imperium und präfigurierte damit den neuzeitlichen Staat. Die hierarchische Struktur der Kirche verteilte Kompetenzen, legte befehlsgewalten und Partizipationen fest. Zuständigkeiten waren auf Räume bezogen', and pp. 108-113. 
thought ${ }^{88}$ Is it because they won the game in the end? Is it because the modern mind rejects the idea of a clerical birth of some of these ideas and of the important role clerics played in the development of an alternative idea of ecclesiastical territory ${ }^{89}$ More broadly, Francis Oakley has shown in his trilogy how much of the Western character of political theory originates in the way clerical ideas and positions were integrated in the debate on power and responsibility, and were used to formulate new theories..$^{9}$

The word 'territory' may have been used rarely by medieval writers with the exception of legists like Bartoldus - but the concept certainly was well known, at least in the matter of ecclesiastical organisation and the structure of the church and its faithful. The concept of a territory definitely existed in the minds of the late medieval clergy, first and foremost of ecclesiastical territory. It also means that elements of this concept were used in debates, in conflicts, and in modes of thinking. ${ }^{11}$ It even influenced theorists of temporal power and respublica as, for example, the fourteenth-century cleric and legal expert Philip of Leyden. He used Justinian's maxim but then with the pope instead of the emperor as 'the living law on earth', the lex animata in terrenis..$^{92}$ How exactly clerical ideas and concepts of ecclesiastical territories like parishes and bishoprics influenced the development of secular notions and practices is still a question that has to be delved into more deeply. The conclusion of Florian Mazel's book on bishops and territory neatly summarises some options here:

Concerning the concept of territory, the Church showed the State the way to proceed in a double way: on the one hand it provided the men and the administrative framework, indispensable for two practices which can be considered as the main instruments of power of the Later Middle Ages: the inquiry and direct taxes. On the other hand, it provided the State, in a more general sense, with a concept of spatial control, construed in

88 Elden, The Birth, pp. 6, 8, and 15-18.

89 Mazel, L'évêque et le territoire, pp. 290-306 and 365-376.

90 Oakley, The Watershed, pp. ix-xv. See in his books the references to, for instance, ecclesiastical jurisdiction, dominium, and spiritual vs. temporal authority.

91 For one of the possible approaches to get a better grip on forms of pre-modern innovation, see the conclusion of Stefan Burkhardt on twelfth-century Mainz: 'Stupentes"', pp. 174-175.

92 Timmer, Profeet, p. 107; Leupen, Philip of Leyden, pp. 188-197; the quote comes from a disputatio of Jan van Borssele $\left(1365^{\dagger}\right)$, professor of law in Paris and a canon of St. Saviour in Utrecht: see Philippus de Leyden, De cura reipublicae, pp. 123-125. 
a territorial way, and not as an aspect of lordship. A concept that was more connected to practices of sovereignty than it pertained to a feudal rationale. 93

\section{Bibliography}

\section{Primary sources}

Bronnen voor de geschiedenis der kerkelijke rechtspraak in het bisdom Utrecht in de middeleeuwen, vol. 6, ed. by J.G.C. Joosting ('s-Gravenhage: Martinus Nijhoff, 1919).

Dierickx, M., ed., Documents inédits sur l'érection des nouveaux diocèses aux Pays-Bas (1521-1570), 3 vols (Bruxelles: Académie Royale de Belgique, 1960-1962).

Het Goudse hofstedengeldregister van ca. 1397 en andere bronnen voor de vroege stadsontwikkeling van Gouda, ed. by K. Goudriaan, B.J. Ibelings and J.C. Visser (Hilversum: Uitgeverij Verloren, 2000).

Enea Silvio Piccolomini - Pius II (1405-1464): een humanistisch paus op de bres voor Europa. Bloemlezing uitzijn brieven en Gedenkschriften, trans. by Michel Goldsteen, introduction and notes by Zweder von Martels and Michel Goldsteen (Hilversum: Uitgeverij Verloren, 2011).

Fairon, Émile, ed., 'Un projet de démembrement du diocèse de Liége proposé par les Brabançons en $133^{2}$ et 1336', Bulletin de la Commission royale d'Histoire 78 (1909), 142-192.

Jansen, A., ed., 'Het advies der commissie van zeven kardinalen omtrent het voorstel van Philips II ter regeling van de bisschoppelijke hierarchie in de Nederlanden', Archief voor de geschiedenis van het Aartsbisdom Utrecht 9 (1881), 1-22.

Philippus de Leyden, De cura reipublicae et sorte principantis, ed. by P.C. Molhuysen ('s-Gravenhage: Martinus Nijhoff, 1915).

Piccolomini, Aeneas Sylvius, Europe (c. 1400-1458), trans. by Robert Brown; intr. and ann. by Nancy Bisaha (Washington, DC: Catholic University of America Press, 2013). Piccolomini, Enea Silvio, Deutschland. Der Brieftraktat an Martin Mayer und Jacob Wimpfelings 'Antworten und Einwendungen gegen Enea Silvio', trans. by Adolf Schmidt (Köln/Graz: Böhlau Verlag, 1962).

93 Mazel, L'évêque et le territoire, p. 373: 'En matière territoriale, l'Église ouvrit donc doublement le chemin à l'État: d'une part en mettant à sa disposition les hommes et le cadre administratif indispensables à la mise en œuvre des deux pratiques qui apparaissent aujourd'hui comme les principaux instruments de l'essor de sa puissance au cours du second Moyen Âge, l'enquête et la fiscalité directe ; d'autre part et de manière plus générale en lui offrant un modèle de domination spatiale d'ordre territorial et non seigneurial, qui relevait d'une logique de souverainité et non d'une logique féodale.' 
Reject Aeneas, Accept Pius. Selected Letters of Aeneas Sylvius Piccolomini (Pope Pius II), trans. by Gerald Christianson, Thomas M. Izbicki, and Philip Krey (Washington, DC: Catholic University of America Press, 2006).

Romeinsche bronnen voor den kerkelijk-staatkundigen toestand der Nederlanden in de 16 de eeuw, ed. by G. Brom and A.H.L. Hensen ('s-Gravenhage: Martinus Nijhoff, 1922).

Schuchard, Christiane, and Knut Schulze, ed., Thomas Giese aus Lübeck und sein römisches Notizbuch der Jahre 1507 bis 1526 (Lübeck: Schmidt-Römhild, 2003).

Zestiende-eeuwsche wandelingen door Nederland. Zwerftochten van Pieter Aelmanszoon, secretaris van Naarden, 1525-1527, ed. by D.Th. Enklaar (Hilversum: De Kroon, 1934).

\section{Secondary sources}

Abulafia, David, 'Introduction: Seven Types of Ambiguity, c. 1100-c. 1500', in Medieval Frontiers: Concepts and Practices, ed. by David Abulafia and Nora Berend (Aldershot: Ashgate, 2002), pp. 1-34.

Akbari, Suzanne Conklin, Idols in the East. European Representations of Islam and the Orient, 1100-145o (Ithaca, NY: Cornell University Press, 2009).

Aubrun, Michel, La paroisse en France des origines au $X V^{e}$ siècle (Paris: Picard, 1986). Aydoğan, Zeynep, 'Changing Perceptions along the Frontiers: The Moving Frontier with Rum in Late Medieval Anatolian Frontier Narratives', in Living in the Ottoman Realm: Empire and Identity, $13^{\text {th }}$ to $20^{\text {th }}$ Centuries, ed. by Christine Isom-Verhaaren and Kent F. Schull (Bloomington: Indiana University Press, 2016), pp. 29-41.

Baldi, Barbara, 'Enea Silvio Piccolomini e il De Europa: umanesimo, religione e politica', Archivio Storico Italiano 161 (2003), 619-683.

Barralis, Christine, et al., eds, Église et État, Église ou État? Les clercs et la genèse de l'État moderne (Rome: Publications de la Sorbonne/École française de Rome, 2014).

Baumgärtner, Ingrid, and Hartmut Kugler, eds, Europa im Weltbild des Mittelalters: kartographische Konzepten (Berlin: Akademie Verlag, 2008).

Bijsterveld, A.J.A., Laverend tussen kerk en wereld. De pastoors in Noord-Brabant 1400-1570 (Amsterdam: VU Uitgeverij, 1993).

Biller, Peter, The Measure of Multitude. Population in Medieval Thought (Oxford: Oxford University Press, 2000).

Bisaha, Nancy, Creating East and West. Renaissance Humanists and the Ottoman Turks (Philadephia: University of Pennsylvania Press, 2004).

Blair, John, 'Les recherches récentes sur la formation des paroisses en Angleterre: similitudes et différences avec la France', Médiévales 49 (La paroisse. Genèse d'une forme territoriale) (2005), 33-44. 
Blair, John, The Church in Anglo-Saxon Society (Oxford: Oxford University Press, 2005).

Bogaers, Llewellyn, Aards, betrokken en zelfbewust. De verwevenheid van cultuur en religie in katholiek Utrecht, 1300-16oo (Utrecht: Levend Verleden, 2008).

Borsche, Tilman, 'Die verborgene Kirche (ecclesia occulta) als verbindende Kraft Europas nach Nikolaus von Kues: De concordantia catholica', in Nikolaus von Kues: Die Großregion als Denk- und Lebensraum, ed. by Harald Schwaetzer and Marie-Anne Vannier (Münster: Aschendorff Verlag, 2019), pp. 49-59.

Bünz, Enno, 'Pfarreien und Pfarrgemeinden im spätmittelalterlichen Deutschland', in Pfarreien in der Vormoderne. Identität und Kultur im Niederkichenwesen Europas, ed. by Michele C. Ferrari and Beat Kümin (Wiesbaden: Harrssowitz Verlag, 2017), pp. 25-59.

Bünz, Enno, and Gerhard Fouquet, eds, Die Pfarrei im späten Mittelalter (Ostfildern: Thorbecke, 2013).

Burkhardt, Stefan, Mit Stab und Schwert. Bilder, Träger und Funktionen erzbischöflicher Herrschaft zur Zeit Kaiser Friedrich Barbarossa. Die Erzbistümer Köln und Mainz im Vergleich (Ostfildern: Thorbecke, 2008).

Burkhardt, Stefan, “Stupentes ob inauditam novitatem”. Das "Neue” im Mainzer Erzstift des 12. Jahrhunderts. Zur Anwendung von Innovationstheorien auf das Mittelalter', VSWG: Vierteljahrschrift für Sozial- und Wirtschaftsgeschichte 97 (2010), 160-175.

Carette, Jeremy R., Foucault and Religion: Spiritual Corporality and Political Spirituality (New York: Routledge, 200o).

Casella, Nicola, 'Pio II tra geografia e storia: La "Cosmographia”, Archivio della Società Romana di Storia Patria 95 (1972), 35-112.

Claeys-Bouüaert, F., 'Évèques', Dictionnaire de droit canonique, 7 vols (Paris: Librairie Letouzey, 1935-1965), vol. 5 [1953], pp. 569-589.

Comte, François, and Emmanuel Grélois, 'La formation des paroisse urbaines: les exemples d'Angers et de Clermont (X $\mathrm{X}^{\mathrm{e}}-\mathrm{XIII}^{\mathrm{e}}$ siècles)', Médiévales 49 (La paroisse. Genèse d'une forme territoriale) (2005), 57-72.

Cosgrove, Denis E., Apollo's Eye: A Cartographic Genealogy of the Earth in the Western Imagination (Baltimore: Johns Hopkins University Press, 2001).

Dekker, C., 'De vorming van aartsdiakonaten in het diocees Utrecht in de tweede helft van de 11e en het eerste kwart van de $12^{\mathrm{e}}$ eeuw', KNAG Geografisch tijdschrift, nieuwe reeks 11 (1977), 339-36o.

Dekker, C., Het Kromme Rijngebied in de Middeleeuwen. Een institutioneelgeografische studie (Zutphen: Walburg Pers, 1983).

De Langen, G., and J.A. Mol, 'Church Foundation and Parish Formation in Frisia in the Tenth and Eleventh Cenruries: A Planned Development?', The Medieval Low Countries 4 (2017), 1-55. 
De Langen, Gilles J., and Johannes A. Mol, 'Church, Landscape, and Power in "Holland" West Frisia up to the Middle of the Eleventh Century: The Bishop, the Count, and the Development of the Parish System in Frisia between Vlie and Zonnemare', The Medieval Low Countries 7 (2020), 9-48.

De Langen, Gilles de, and Hans Mol, 'Kerk, macht en ruimte in Holland tot het midden van de 11 de eeuw. De uitbouw van het parochiewezen tussen Maas en Vlie', Holland Historisch Tijdschrift 50 (2018), 264-273.

De Moreau, E., Histoire de l'Église en Belgique, tome complémentaire I, texte, circonscriptions ecclésiastiques (Bruxelles: L'Édition Universelle, 1948).

Dierickx, M., De oprichting der nieuwe bisdommen in de Nederlanden onder Filips II 1559-1570 (Antwerpen en Utrecht: Standaard en Spectrum, 1950).

Duffy, Eamon, The Stripping of the Altars. Traditional Religion in England, c. 1400-c. 1580 (New Haven/London: Yale University Press, 1992).

Duffy, Eamon, The Voices of Morebath. Reformation and Rebellion in an English Village (New Haven/London: Yale University Press, 2001).

Elden, Stuart, The Birth of Territory (Chicago: University of Chicago Press, 2013).

Elden, Stuart, Foucault: The Birth of Power (Cambridge: Polity Press, 2017).

Elden, Stuart, 'How Should We Do the History of Territory?', Territory, Politics, Governance 1, no. 1 (2013), 5-20.

Ellenblum, Ronnie, 'Were There Borders and Borderlines in the Middle Ages? The Example of the Latin Kingdom of Jerusalem', in Medieval Frontiers: Concepts and Practices, ed. by David Abulafia and Nora Berend (Aldershot: Ashgate, 2002), pp. 105-119.

Enklaar, D.Th., 'De oudste kaarten van het Gooiland en zijn grensgebieden', Nederlandsch Archievenblad 39 (1931/1932), 185-205.

Esch, Arnold, Landschaften der Frührenaissance. Auf Ausflug mit Pius II (München: Verlag C.H. Beck, 2008).

Falk, Seb, The Light Ages. A Medieval Journey of Discovery (London: Penguin Random House, 2020).

Favier, Jean, Un roi de marbre (= Philippe le Bel (1978) and Enguerran de Marigny (1963)) (Villeneuve d'Asq: Fayard, 2005).

Feine, Hans Erich, Kirchliche Rechtsgeschichte. Die Katholische Kirche (Köln/Wien: Böhlau Verlag, 1972).

Finke, Heinrich, 'Die Nation in den spätmittelalterlichen allgemeinen Konzilien', Historisches Jahrbuch 57 (1937), 323-338.

Gebel, Doris, Nikolaus von Kues und Enea Silvio Piccolomini. Bilder der außereuropäischen Welt als Spiegelung europäischer Sozialverhältnisse im 15. Jahrhundert, PhD thesis, Hamburg 1977.

Goetz, Hans-Werner, 'Discourses on Purity in Western Christianity in the Early and High Middle Ages', in Discourses of Purity in Transcultural Perspective 
(300-16oo), ed. by Stefan Kock, Nikolas Jaspert and Matthias Bley (Boston/ Leiden: Brill, 2015), pp. 116-150.

Goossens, Th., Franciscus Sonnius in de pamfletten. Bijdragen tot zijne biografie ('s-Hertogenbosch: G. Mosmans, 1917).

Groeneveld, Jaap, 'De oostgrens van het Gooi. De geschiedenis van de verschillende grensvakken', Historische Kring Eemnes 28 (2006), 115-131.

Haarländer, Stephanie, Vitae episcoporum: eine Quellengattung zwischen Hagiographie und Historiographie, untersucht an Lebensbeschreibungen von Bischöfen des Regnum Teutonicum im Zeitalter der Ottonen und Salier (Stuttgart: Hiersemann, 2000).

Halfond, Gregory, 'Review: Florian Mazel, L'évêque et le territoire', Church History 87 (2018), 189-191.

Harvey, P.D.A., ed., The Hereford World Map: Medieval World Maps and Their Context (London: The British Library, 2006).

Hautefeuille, Florent, 'La cartographie de la paroisse et ses difficultés de réalisation', in Aux origines de la paroisse rurale en Gaule méridionale (IV $V^{e} I X^{e}$ siècles), ed. by Christine Delaplace (Paris: Éditions Errances, 2003), pp. 24-32.

Hautefeuille, Florent, 'La délimitation des territoires paroissiaux dans les pays de moyenne Garonne ( $\mathrm{X}^{\mathrm{e}}-\mathrm{XV}^{\mathrm{e}}$ siècles)', Médiévales 49 (La paroisse. Genèse d'une forme territoriale) (2005), 73-88.

Hay, Denys, Europe: The Emergence of an Idea (Edinburgh: Edinburgh University Press, 1957).

Hirschi, Caspar, 'Das humanistische Nationskonstrukt vor dem Hintergrund modernistischer Nationalismustheorien', Historisches Jahrbuch 122 (2002), 46-66.

Hirschi, Caspar, The Origins of Nationalism. An Alternative History from Ancient Rome to Early Modern Germany (Cambridge: Cambridge University Press, 2012). Holland, Nancy J., “'Truth as Force”: Michel Foucault on Religion, State Power, and the Law', Journal of Law and Religion 18 (2002-2003), 79-97.

Iogna-Prat, Dominique, La Maison Dieu. Une histoire monumentale de l'Église au Moyen Âge (Paris: Seuil, 2006).

Janssen, Wilhelm, Das Erzbistum Köln im späten Mittelalter 1191-1515 (Köln: J.P. Bachem Verlag, 1995).

Janssen, Wilhelm 'Die Differenzierung der Pfarrorganisation in der spätmittelalterlichen Erzdiözese Köln. Bemerkungen zum Verhältnis von "capella dotata”, "capella curata" und "ecclesia parochialis", Rheinische Vierteljahrsblätter 55 (1991), 58-83.

Jongkees, A.G., Staat en kerk in Holland en Zeeland onder de Bourgondische hertogen 1425-1477 (Groningen en Batavia: Wolters, 1942).

Karageorgos, Basileios, 'Der Begriff Europa im Hoch- und Spätmittelalter', Deutsches Archiv für Erforschung des Mittelalters 48 (1992), 137-164. 
Kempshall, M.S., The Common Good in Late Medieval Political Thought (Oxford: Clarendon Press, 1999).

Kibre, Pearl, The Nations in the Mediaeval Universities (Cambridge, MA: Mediaeval Academy of America, 1948).

Klueting, Edeltraut, Harm Klueting and Hans-Joachim Schmidt, eds, Bistümer und Bistumsgrenzen vom frühen Mittelalter bis zur Gegenwart (Rome: Herder, 2006).

Krah, Adelheid, '“Natio”, nicht Nation?', Francia. Forschungen zur westeuropäischen Geschichte 45 (2018), 241-262.

Kuys, Jan, Kerkelijke organisatie in het middeleeuwse bisdom Utrecht (Nijmegen: Valkhof Pers, 2004).

Lambrecht, D., De parochiale synode in het oude bisdom Doornik gesitueerd in de

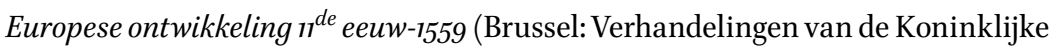
Academie voor Wetenschappen, Letteren en Schone Kunsten van België, 1984).

Lauwers, Michel, Naissance du cimetière. Lieux sacrés et terre des morts dans l'Occident médiéval (Paris: Aubier, 2005).

Lauwers, Michel, 'Paroisse, paroissiens et territoire. Remarques sur parochia dans les textes latins du Moyen Âge', Médiévales 49 (La paroisse. Genèse d'une forme territoriale) (2005), 11-32.

Leturq, Samuel, 'Territoires agraires et limites paroissiales', Médiévales 49 (La paroisse. Genèse d'une forme territoriale) (2005), 89-103.

Leupen, Piet, Philip ofLeyden. A Fourteenth Century Jurist (The Hague and Zwolle: Leiden University Press and Tjeenk Willink, 1981).

Mazel, Florian, Féodalités 880-118o (Paris: Belin, 2010).

Mazel, Florian, L'évêque et le territoire. L'invention médiévale de l'espace ( $V^{e}$-XIII siècle) (Paris: Seuil, 2016).

Meserve, Margaret, Empires ofIslam in Renaissance Historical Thought (Cambridge, MA: Harvard University Press, 2008).

Meserve, Margaret, 'From Samarkand to Scythia: Reinventions of Asia in Renaissance Geography and Political Thought', in Pius II, 'el piu expeditivo pontefice': Selected Studies on Aeneas Silvius Piccolomini (1405-1464), ed. by Zweder R.W.M. von Martels and Arjo Vanderjagt (Boston/Leiden: Brill, 2003), pp. 13-40.

Möller, Steffen, 'Nicolaus Cusanus als Geograph', in Das europäische Erbe im Denken des Nikolaus von Kues. Geistesgeschichte als Geistesgegenwart, ed. by Harald Schwaetzer and Kirstin Zeyer (Münster: Aschendorff Verlag, 2008), pp. 215-227.

Moolenbroek, J.J. van, 'Zeeuwen in verzet tegen hun kerkelijke rechters. Een enquête in het jaar 1505', Tijdschrift voor Geschiedenis 100 (1987), 507-532.

Moritz, Arne, 'Concordantia als normatives Prinzip der Herrschaft über Freie und Gleiche. Nikolaus von Kues innerhalb der Geschichte der europäischen Demokratie', in Das europäische Erbe im Denken des Nikolaus von Kues. Geistesgeschichte 
als Geistesgegenwart, ed. by Harald Schwaetzer and Kirstin Zeyer (Münster: Aschendorff Verlag, 2008), pp. 257-282.

Muller Hzn., S., De indeeling van het bisdom ('s-Gravenhage: Martinus Nijhoff, 19o6). Nikolaus von Kues: Die Großregion als Denk-und Lebensraum, ed. by Harald Schwaetzer and Marie-Anne Vannier (Münster: Aschendorff Verlag, 2019).

Noizet, Hélène, 'De l'église au territoire: les paroisses à Tours (XI'-XIII ${ }^{\mathrm{e}}$ siècles)', Médiévales 49 (La paroisse. Genèse d'une forme territoriale) (2005), 45-56.

Noizet, Hélène, Xavier Rodier and Elisabeth Zadora-Rio, 'Débat à propos Des paroisses de Touraine aux communes d'Indre-et-Loire. La formation des territoires: une lecture critique d'Hélène Noizet, avec les réponses des auteurs de l'ouvrage', Les petits cahiers d'Anatole 23 (2013), 2-26, http://citeres.univ-tours.fr/doc/lat/ pecada/pecada_23.pdf.

Oakley, Francis, The Mortgage of the Past: Reshaping the Ancient Political Inheritance (1050-1300) (New Haven/London: Yale University Press, 2012).

Oakley, Francis, The Watershed of Modern Politics: Law, Virtue, Kingship, and Consent (1300-1650) (New Haven/London: Yale University Press, 2015).

O'Brien, Emily, The Commentaries of Pope Pius II (1458-1464) and the Crisis of the Fifteenth-Century Papacy (Toronto: University of Toronto Press, 2015).

Oschema, Klaus, Bildervon Europa im Mittelalter (Ostfildern:Jan Thorbecke Verlag, 2013). Patzold, Steffen, Episcopus. Wissen über Bischöfe im Frankenreich des späten 8. bis frühen 10. Jahrhunderts (Ostfildern: Jan Thorbecke Verlag, 2008).

Postma, Folkert, 'Nieuw licht op een oude zaak: de oprichting van de nieuwe bisdommen in 1559', Tijdschrift voor Geschiedenis 103 (1990), 10-27.

Postma, Folkert, Viglius van Aytta. De jaren met Granvelle 1549-1564 (Zutphen: Walburg Pers, 2000).

Rapp, Claudia, Holy Bishops in Late Antiquity: The Nature of Christian Leadership in an Age of Transition (Berkeley: University of California Press, 2005).

Rawcliffe, Carole, Urban Bodies: Communal Health in Late MedievalEnglish Towns and Cities (Woodbridge: The Boydell Press, 2013).

Reinhardt, Volker, Pius II. Piccolomini. Der Papst, mit dem die Renaissance begann.

Eine Biographie (München: Verlag C.H. Beck, 2013).

Reynolds, Susan, Fiefs and Vassals: The Medieval Evidence Reinterpreted (Oxford: Oxford University Press, 1994).

Reynolds, Susan, Kingdoms and Communities in Western Europe, 900-1300, $2^{\text {nd }}$ ed. (Oxford: Clarendon Press, 1997).

Robinson, David, Beneficed Clergy in Cleveland and the East Riding, 1306-1340 (York: St. Anthony's Press, 1970).

Schmidinger, Heinrich, Romana regia potestas. Staats- und Reichsdenken bei Engelbert von Admont und Enea Silvio Piccolomini (Basel/Stuttgart: Helbing \& Lichtenhahn, 1978). 
Schmidt, Hans-Joachim, 'Einleitung', in Bistümer und Bistumsgrenzen vom frühen Mittelalter bis zur Gegenwart, ed. by Edeltraut Klueting, Harm Klueting and Hans-Joachim Schmidt (Rome: Herder, 2006), pp. 9-12.

Schmidt, Hans-Joachim, 'Neugliederung der Bistümer und Kirchenprovinzen in Südfrankreich und in Aragón zu Beginn des 14. Jahrhunderts', in Bistümer und Bistumsgrenzen vom frühen Mittelalter bis zur Gegenwart, ed. by Edeltraut Klueting, Harm Klueting and Hans-Joachim Schmidt (Rome: Herder, 2006), pp. 107-125.

Schmidt, Hans-Joachim, 'Raumkonzepte und geographische Ordnung kirchlicher Institutionen im 13. Jahrhundert', in Raumerfassung und Raumbewußtsein im späten Mittelalter, ed. by Peter Moraw (Stuttgart: Thorbecke Verlag, 2002), pp. 87-125.

Schmieder, Felicitas, 'Edges of the World - Edges of Time', in The Edges of the Medieval World, ed. by Gerhard Jaritz and Juhan Kreem (Budapest/New York: Central European University Press, 2009), pp. 4-20.

Schwaetzer, Harald, 'Nikolaus von Kues - ein Mentor für Europa', in Nikolaus von Kues:Die Großregion als Denk- und Lebensraum, ed. by Harald Schwaetzer and Marie-Anne Vannier (Münster: Aschendorff Verlag, 2019), pp. 11-40.

Stein, Robert, Anita Boele and Wim Blockmans, 'Whose Community? The Origin and Development of the Concept of Bonum Commune in Flanders, Brabant and Holland (Twelfth-Fifteenth Century)', in De Bono Communi: The Discourse and Practice of the Common Good in the European City $\left(13^{\text {th }}-16^{\text {th }}\right.$ Century), ed. by Elodie Lecuppre-Desjardin and Anne-Laure Van Bruaene (Turnhout: Brepols, 2010), pp. 149-169.

Strenski, Ivan, 'Religion, Power, and Final Foucault', Journal of the American Academy of Religion 66 (1998), 345-367.

Swanson, R.N., Church \& Society in Late Medieval England (Oxford: Blackwell, 1993). Swanson, Robert, 'Gens secundum cognationem et collectionem ab alia distincta? Thomas Polton, Two Englands, and the Challenge of Medieval Nationhood', in Das Konstanzer Konzil als europäischer Ereignis: Begegnungen, Medien, Rituale, ed. by Gabriela Signori and Birgit Studt (Ostfildern: Thorbecke, 2014), pp. 57-87.

Tewes, Götz-Rüdiger, 'Das spätmittelalterliche Papsttum und die Problematik der Raumerfassung', in Raum und Raumvorstellungen im Mittelalter, ed. by Jan A. Aertsen and Andreas Speer (Berlin/New York: Walter de Gruyter, 1998), pp. 6o3-612.

Tewes, Götz-Rüdiger, Die römische Kurie und die europäischen Länder am Vorabend der Reformation (Tübingen: Max Niemeyer Verlag, 2001).

Tewes, Götz-Rüdinger, 'Zwischen Universalismus und Partikularismus: Zum Raumbewußtsein an der päpstlichen Kurie des Spätmittelalters', in Raumerfassung und Raumbewußtsein im späten Mittelalter, ed. by Peter Moraw (Stuttgart: Thorbecke, 2002), pp. 31-85. 
Timmer, Rijk, Profeet in eigen land. Philips van Leiden en het publiek belang (Hilversum: Verloren, 2008).

Tolan, John, 'Conquest and Its Justifications: Jihad, Crusade, Reconquista', in Europe and the Islamic World: A History, ed. by John Tolan, Gilles Veinstein and Henry Laurens (Princeton: Princeton University Press, 2013), pp. 27-48.

Tolan, John V., Saracens: Islam in the Medieval European Imagination (New York: Columbia University Press, 2002).

Van den Hoven van Genderen, Bram, Het kapittel-generaal en de staten van het Nedersticht in de $15^{e}$ eeuw (Zutphen: Walburg Pers, 1987).

Van den Hoven van Genderen, Bram, 'Registers en rekeningen: een voorbeeld van middeleeuwse administratie en verschriftelijking', De kerk en de Nederlanden. Archieven, instellingen, samenleving, ed. by E.S.C. Erkelenz-Buttinger et al. (Hilversum: Verloren, 1997), pp. 168-188.

Van den Hoven van Genderen, Bram, “'Utrechtse Vlamingen”. De Vier Ambachten vanuit het noorden: Utrechtse lenen en tienden in de middeleeuwen', in Hulst in de Middeleeuwen en de kroniek van haar haven (Hulst: Oudheidkundige Kring "De Vier Ambachten", 2017), pp. 139-185.

Van der Haegen, Herman, De eerste Vlaamse ruimte. De kerkelijke driedeling van de Nederlanden in 1559. Een historisch-geografische analyse (Hofstade: Doorbraak, 2017).

Van der Krogt, Peter, 'Lokale kaarten van Nederland uit de late Middeleeuwen', Caert-Thresoor 27 (2008), 29-42.

Van Rhijn, Carine, Shepherds of the Lord: Priests and Episcopal Statutes in the Carolingian Period (Turnhout: Brepols, 2007).

Voigt, Klaus, Italienische Berichte aus dem spätmittelalterlichen Deutschland. Von Francesco Petrarca zu Andrea de' Franceschi (Stuttgart: Ernst Klett Verlag, 1973).

Vollmann, Benedikt Konrad, 'Aeneas Silvius Piccolomini as a Historiographer: Asia', in Pius II, 'el piu expeditivo pontefice': Selected Studies on Aeneas Silvius Piccolomini (1405-1464), ed. by Zweder R.W.M. von Martels and Arjo Vanderjagt (Boston/Leiden: Brill, 2003), pp. 41-54.

Von den Brincken, Anna-Dorothee, 'Descriptio Terrarum. Zur Repräsentation von bewohnten Raum im späteren deutschen Mittelalter', in Raumerfassung und Raumbewußtsein im späten Mittelalter, ed. by Peter Moraw (Stuttgart: Thorbecke Verlag, 2002), pp. 11-30.

Von den Brincken, Anna-Dorothee, Fines Terrae: die Enden der Erde und der vierte Kontinent aufmittelalterlichen Weltkarten (Hannover: Hahn, 1992).

Watanabe, Morichimi, 'Imperial Reform in the Mid-Fifteenth Century: Gregor Heimburg and Martin Mair', The Journal of Medieval and Renaissance Studies 9 (1979), 209-235. 
Watanabe, Morichimi, The Political Ideas of Nicholas of Cusa with Special Reference to His De Concordantia Catholica (Genève: Librairie Droz, 1963).

Watanabe, Morichimi, and Thomas M. Izbicki, 'Nicholas of Cusa, a General Reform of the Church', in Nicholas of Cusa on Christ and the Church. Essays in Memory of Chandler McCuskey Brooks for the American Cusanus Society, ed. by Gerald Christianson and Thomas M. Izbicki (Leiden/Köln: Brill, 1996), pp. 175-202.

Weber, Benjamin, Lutter contre les Turcs. Les formes nouvelles de la croisade pontificale au $X V^{e}$ siècle (Rome: École Française de Rome, 2013).

Weis, Monique, 'Die spanisch-niederländische Hierarchie und die Diözesanneuordnung in den Niederlanden unter Philipp II', in Bistümer und Bistumsgrenzen vom frühen Mittelalter bis zur Gegenwart, ed. by Edeltraut Klueting, Harm Klueting and Hans-Joachim Schmidt (Rome: Herder, 2006), pp. 158-169.

Wood, Susan, The Proprietary Church in the Medieval West (Oxford: Oxford University Press, 2006).

Zadora-Rio, Elisabeth, 'L'historiographie des paroisses rurales à l'épreuve de l'archéologie', in Aux origines de la paroisse rurale en Gaule méridionale (IVe-IX siècles), ed. by Christine Delaplace (Paris: Éditions Errances, 2003), pp. 15-23.

Zadora-Rio, Elisabeth, 'The Making of Churchyard and Parish Territories in the Early Medieval Landscape of France and England in the $7^{\text {th }}-12^{\text {th }}$ Centuries: A Reconsideration', Mediaeval Archaeology 47 (2003), 1-19.

Zadoro-Rio, Elisabeth, 'Territoires paroissiaux et construction de l'espace vernaculaire', Médiévales 49 (La paroisse. Genèse d'une forme territoriale) (2005), 105-119.

\section{About the author}

Bram van den Hoven van Genderen is a Lecturer in Medieval History at Utrecht University. He publishes regularly on the religious, political, and social history of the Later Middle Ages, often taking Utrecht and its prince-bishopric as a starting point. 
